\title{
Entorhinal-hippocampal neuronal circuits bridge temporally discontiguous events
}

\author{
Takashi Kitamura, ${ }^{1,3}$ Christopher J. Macdonald, ${ }^{1,3}$ and Susumu Tonegawa ${ }^{1,2}$ \\ ${ }^{1}$ RIKEN-MIT Center for Neural Circuit Genetics at the Picower Institute for Learning and Memory, Department of Biology and \\ Department of Brain and Cognitive Sciences, Massachusetts Institute of Technology, Cambridge, Massachusetts 02139, USA; \\ ${ }^{2}$ Howard Hughes Medical Institute at MIT, Cambridge, Massachusetts 02139, USA
}

\begin{abstract}
The entorhinal cortex (EC)-hippocampal (HPC) network plays an essential role for episodic memory, which preserves spatial and temporal information about the occurrence of past events. Although there has been significant progress toward understanding the neural circuits underlying the spatial dimension of episodic memory, the relevant circuits subserving the temporal dimension are just beginning to be understood. In this review, we examine the evidence concerning the role of the EC in associating events separated by time-or temporal associative learning-with emphasis on the function of persistent activity in the medial entorhinal cortex layer III (MECIII) and their direct inputs into the CAl region of HPC. We also discuss the unique role of Island cells in the medial entorhinal cortex layer II (MECII), which is a newly discovered direct feedforward inhibitory circuit to CA1. Finally, we relate the function of these entorhinal cortical circuits to recent findings concerning hippocampal time cells, which may collectively activate in sequence to bridge temporal gaps between discontiguous events in an episode.
\end{abstract}

Episodic memory enables us to remember where and when a distinct sequence of events occurred in our past. Indeed, one of the hallmark features of episodic memories is that they are temporally organized (Tulving 1984). This feature places a constraint on its underlying neurobiology. Spike timing-dependent plasticity (Bi and Poo 1998) can accommodate associative learning between events that cooccur or follow one another within very short time windows. However, in order for an organism to accurately encode associative and temporal relationships between events that span longer temporal scales, there must exist mechanisms for plasticity that can overcome time intervals ranging from a second to a few tens of seconds. Hereafter, we refer to this aspect of encoding as temporal associative learning and assume that the episodic memory system engages this process.

Converging evidence from human and animal studies point to entorhinal cortical (EC)-hippocampal (HPC) circuits as being critical for episodic memory, and in particular for temporal associative learning (Eichenbaum 2014, MacDonald 2014). In this regard, Pavlovian conditioning protocols (Maren 2001) have proven especially useful. For example, in delay fear conditioning, a neutral conditioned stimulus (CS), such as a tone, can be reliably paired with a noxious unconditioned stimulus (US), like a mild footshock, so that the two events overlap and coterminate in time (Fig. 1). As the predictive relationship between the CS and US is learned, subsequent presentations of the CS alone (recall trials) elicit a conditional response, such as freezing. In trace fear conditioning the CS reliably precedes the US, but the two events are separated by a stimulus-free, constant time-interval known as a "trace" (Fig. 1). These two protocols, along with additional control conditions (e.g., unpaired pseudo-random CS-US presentations), provide a powerful means to evaluate the contribution of different brain regions to temporal associative learning. For these reasons, in this review we focus discussion primarily on these behavioral paradigms, the functional dissections of the EC-HPC

\footnotetext{
${ }^{3}$ These authors contributed equally to this work.

Corresponding author: tonegawa@mit.edu

Article is online at http://www.learnmem.org/cgi/doi/10.1101/lm.038687. 115.
}

circuits and the physiological mechanisms that subserve temporal aspects of episodic memory, although there are reviews that discuss additional physiological mechanisms of temporal associative learning (Hasselmo and Stern 2006; Yoshida et al. 2012; Eichenbaum 2014).

\section{The hippocampal CA1 area supports temporal associative learning}

Many animal studies have shown that the HPC is needed for establishing CS-US associations across the empty temporal gap imposed by the trace (Solomon et al. 1986; Moyer et al. 1990). For example, large hippocampal, but not neocortical lesions given prior to training impaired learning in rats that were trace fear conditioned, and hippocampal damage had largely no effect on delay fear conditioning (McEchron et al. 1998). The selective role for the HPC in trace conditioning is also consistent with human amnesic studies (Clark and Squire 1998). As in humans, the rodent hippocampus can be divided into the dentate gyrus, CA3, CA2, and CA1 regions (Andersen et al. 2007). In one of the main excitatory pathways, layer II stellate cells of EC project to granule cells in the DG through the perforant path, from the DG to CA3 pyramidal cells through the mossy fibers, from CA3 pyramidal cells to CA1 pyramidal cells through the Schaffer collaterals, and finally project back to the cells in layer V of EC. In addition, layer III pyramidal cells of EC directly project to CA1 pyramidal cells (Amaral and Witter 1989). Because the HPC is composed of several interconnected subregions, it becomes important to define each of their specific contributions, or lack thereof, to temporal associative learning.

To this end, Kesner and colleagues have extensively investigated the differential roles of various hippocampal subregions.

\footnotetext{
(C) 2015 Kitamura et al. This article is distributed exclusively by Cold Spring Harbor Laboratory Press for the first 12 months after the full-issue publication date (see http://learnmem.cshlp.org/site/misc/terms.xhtml). After 12 months, it is available under a Creative Commons License (AttributionNonCommercial 4.0 International), as described at http://creativecommons. org/licenses/by-nc/4.0/.
} 
Trace fear conditioning

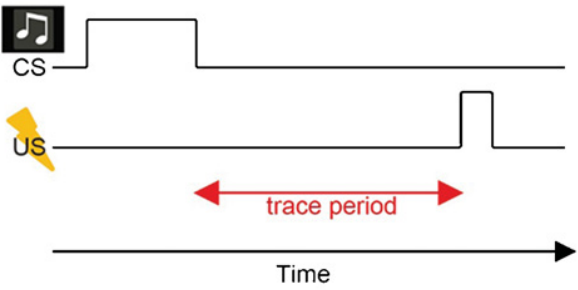

Delay fear conditioning

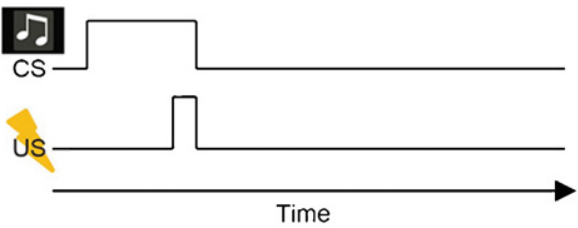

Figure 1. Delay fear conditioning and trace fear conditioning. Trace fear conditioning has a temporal gap between tone (CS) and aversive electrical footshock (US), whereas delay fear conditioning does not.

They found that the CA1 lesions disrupted learning when events to be associated were separated in time but not presented together, and this is not the case for CA3 (for review, see Kesner 2013, Kesner et al. 2005). This is consistent with findings from Huerta et al. (2000) who subjected hippocampal CA1 pyramidal cell-specific-NMDA receptor knockout mice (Tsien et al. 1996) to trace fear conditioning. The mutant mice could not associate the tone CS with an aversive US (footshock) across a trace interval. Conversely, they acquired the conditional response when the trace interval was removed (delay fear conditioning) (Fig. 1). By leveraging region and cell-type specificity of a genetically based approach, this study established that an NMDA-related process specifically in CA1 pyramidal cells may be critical for temporal associative learning.

\section{Entorhinal cortex layer III input to the hippocampus is crucial for temporal associative learning}

Although the HPC had long been considered important for trace conditioning, interest in the role of the EC developed relatively recently. Ryou et al. (2001) first demonstrated that large nonselective EC lesions impair the acquisition of trace, but not delay eyeblink conditioning in rabbits. Consistent with this finding, following neurotoxic lesions encompassing much of the EC in rats, rats showed a selective impairment in the acquisition of trace fear but not delay fear conditioning (Esclassan et al. 2009). In addition, although one study reported no effect on trace eyeblink conditioning after electrolytic lesions of lateral EC (LEC) prior to training (Suter et al. 2013), reversible inactivation of the LEC area after training with the area intact did impair tone recall (Morrissey et al. 2012). Taken together, lesion studies indicate that temporal associative learning depends on the integrity of the EC.

However, because those studies did not use cell type-specific manipulations of the EC, the precise neural circuits within the EC-HPC network serving this type of association remained unknown. The EC provides inputs to the HPC via two major projections: the trisynaptic pathway originating from ECII stellate cells and projecting to the DG and the monosynaptic pathway originating from ECIII and sending inputs to the CA1 region (Fig. 2A; Kohara et al. 2014). Studies on genetically engineered mice (Nakazawa et al. 2004) and lesioned rats (Kesner et al. 2000; Brun et al. 2002) have demonstrated crucial roles of the trisynaptic pathway in spatial learning and in several other features of episodic memory, such as pattern completion and separation (Marr 1971; Nakazawa et al. 2002; Leutgeb et al. 2007; McHugh et al. 2007).

To better understand the contributions of the direct pathway from ECIII to hippocampal CA1 to episodic memory, Suh et al. (2011) created a mutant-mice strain, in which the output of the dorsal medial ECIII (dMECIII) was specifically blocked by the expression of tetanus-toxin (TeTX) in dMECIII. The dMEC-TeTX mutant mice showed deficits in trace fear conditioning with a 20 -sec time interval. Conversely, the mutant mice did not show any deficit in delay fear conditioning. Interestingly, the mutant mice also exhibited severe deficits in tasks designed to test spatial working memory, but which also place demands on temporal associative learning. For example, in a delayed nonmatchingto-place (DNTP) task, mice were forced to take one spatial route through a T-maze during a sample trial (e.g., left turn), and then after a 15- to 30-sec delay take the opposite route (e.g., right turn) to obtain food reward on a test trial when they are given a free choice. In contrast, the mutant-mice in which the output of the hippocampal CA3 cells (Nakashiba et al. 2008) was specifically blocked by TeTX were normal in trace fear conditioning (Suh et al. 2011), suggesting that the hippocampal trisynaptic pathway may be dispensable for temporal associative learning.

Persistent firing has been defined as repetitive spiking activity of neurons that persists even after the triggering stimulus has been removed (Frank and Brown 2003; Major and Tank 2004) and is observed in a variety of brain regions including the MEC, hippocampal CA1 in vitro (Egorov et al. 2002; Knauer et al. 2013). The persistent firing of neurons in the MECIII (Yoshida et al. 2008) may be one mechanism that contributes to temporal associative learning (Fig. 2B). First, as this persistent firing in MECIII cells in vitro depends on activation of the metabotropic glutamate receptor 1 (mGluR1) and cholinergic muscarinic

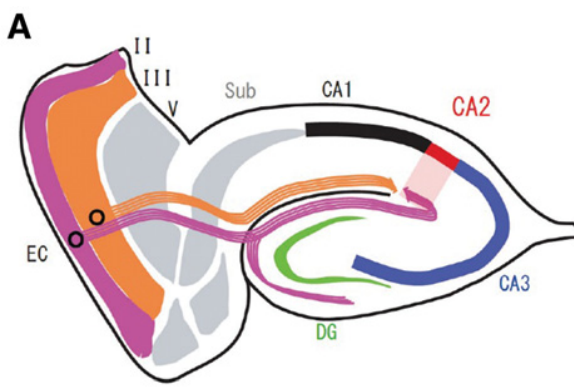

B

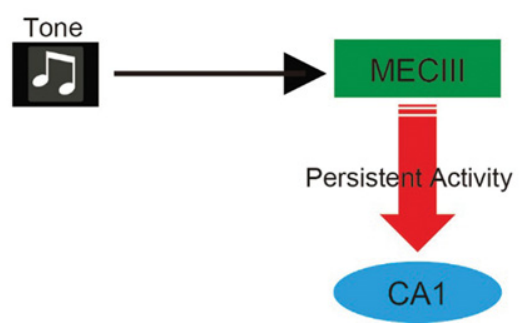

Figure 2. MECIII input to hippocampal CA1 is crucial for trace fear conditioning. (A) Diagram of entorhinal hippocampal circuits. Stellate Ocean cells (purple) in ECII project to the DG, CA3, and CA2 region, whereas ECIII cells (orange) directly project to the CA1 region. (B) Possible mechanisms. Tone-induced MECIII persistent activity may activate the CA1 pyramidal cells to bridge the temporal gap during the trace period of memory task. 
receptors (Egorov et al. 2002; Yoshida et al. 2008; Jochems et al. 2013), cholinergic deafferentation in EC or local injection of a muscarinic receptor antagonist into EC results in a trace fear conditioning deficit (Esclassan et al. 2009). Second, the injection of a mixture of their respective antagonists for mGluR1 and cholinergic muscarinic receptors into the dMEC inhibits trace fear conditioning in control mice, but not in dMECIII-TeTX mutant mice (Suh et al. 2011). Finally, as described earlier the dMECIII-TeTX mutant mice had deficits in a DNMP task (Suh et al. 2011; Yamamoto et al. 2014). Yamamoto et al. (2014) found ramping phasic multiunit activity (MUA) bursts in dMECIII during test trials of the DNMP task in control animals. The MUA bursts of dMECIII in the dMECIII-TeTX mutant mice during test trials were much weaker than those in control mice. This difference suggests a relationship between in vivo MUA ramping and persistent firing observed in vitro.

\section{Island cells in layer II entorhinal cortex control temporal associative learning}

Like most cognitive and motor phenomena, temporal associative learning also must be regulated for optimal adaptive benefit. The regulation is crucial for optimal adaptive benefit; too strong an association between a particular pair of events may interfere with associations of other useful pairs, whereas too weak an association for a given pair of events will not result in an effective memory. However, until recently virtually nothing was known about the underlying mechanisms of this regulation and about the identification of neural circuits that control this temporal association.

Recently, Kitamura et al. (2014) discovered unsuspected new circuits in the EC-HPC network that regulate temporal associative learning. EC layer II contains two types of excitatory neurons, which are stellate cells and pyramidal cells (Alonso and Klink 1993; Klink and Alonso, 1997). Kitamura et al. (2014) and Ray et al. (2014) found that the pyramidal cells appear in a hexagonal curvilinear matrix of bulblike structures in ECII, and that stellate cells surrounded these pyramidal cell-clusters. We refer to these stellate cells as "Ocean cells" and these pyramidal cells as "Island cells" (Kitamura et al. 2014). Island cells are also distinct from ocean cells not only by their morphology (Alonso and Klink 1993; Klink and Alonso 1997) but also by molecular markers (Varga et al. 2010; Kitamura et al. 2014; Ray et al. 2014), their intrinsic electrophysiological properties (Alonso and Klink 1993; Kitamura et al. 2014) and their projection patterns (Tamamaki and Nojyo 1993; Varga et al. 2010; Kitamura et al. 2014). Stellate Ocean cells project to the dentate gyrus to form the trisynaptic pathway as previously reported (Tamamaki and Nojyo 1993; Varga et al. 2010). By using Island cell-specific axonal tracing combined with optogenetic activations of Island cells Kitamura et al. (2014) discovered that pyramidal Island cells directly project to stratum lacunosum (SL) of CA1 region to synapse with the GABAergic interneurons in SL (SL-INs) (Fig. 3A). In contrast, MECIII cells axons innervate the stratum moleculare (SM) immediately adjacent to the SL. Thus, there is laminar structure between Island cell input into SL and MECIII input into SM. This strategic location of SL-INs, the primary target of Island cells, immediately adjacent to the inner side of the SM layer where MECIII cells synapse to the distal dendrites of CA1 pyramidal cells enables Island cells to suppress MECIII input by feedforward inhibition (Fig. 3B; Kitamura et al. 2014). This is consistent with previous studies pointing to the existence of a feedforward inhibitory circuit arising from direct entorhinal inputs into CA1 (Remondes and Schuman 2002). SL-INs are connected by gap junctions (Price et al. 2005). Thus, activation of Island cell axons can evoke a depolarizing response broadly among SL-INs, which may propagate
A
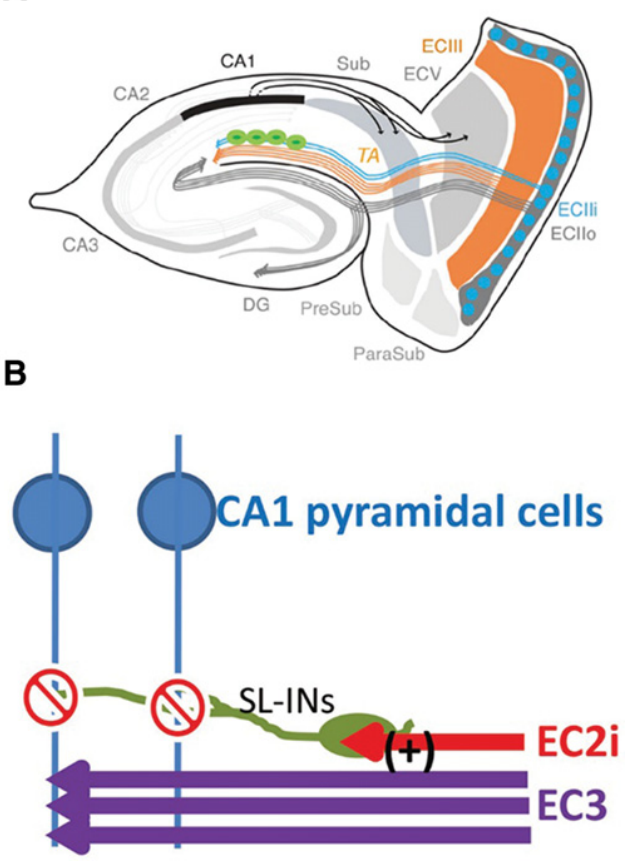

Figure 3. Island cells gate the MECIII input into the CA1 pyramidal cells through the feedforward inhibition. $(A)$ New diagram of entorhinal hippocampal circuits. Pyramidal Island cells (blue, ECIli) directly project to stratum lacunosum (SL) of CA1 region to synapse with the GABAergic interneurons (green) in SL (SL-INs). (B) Strategic location of SL-INs and projections from MECIII and Island cells. Island cells axons innervate the stratum lacunosum (SL), whereas MECIII cells axons innervate the stratum moleculare (SM) immediately adjacent to the SL. This strategic location of SL-INs (green), the primary target of Island cells, immediately adjacent to the inner side of the SM layer where MECIII cells synapse to the distal dendrites of CA1 pyramidal cells (blue) enables Island cells (Morrissey et al. 2012) to suppress MECIII input (purple) by feedforward inhibition.

through gap junctions and amplify the effect of Island cell inputs to suppress MECIII input to CA1 distal dendrites.

Kitamura et al. optogenetically manipulated Island and MECIII cells by expressing ChR2 or ArchT (Han et al. 2011; Mattis et al. 2012) during the training session of trace fear conditioning (Kitamura et al. 2014). Optogenetic inhibition of MECIII input or activation of Island cells input caused learning deficits in trace fear conditioning but not in contextual fear conditioning, which involves learning to associate a spatial context with an aversive electrical footshock, indicating evidence for inhibition of the MECIII input into CA1 cells by the Island cell through feedforward inhibition. This is reinforced by the data showing that ArchT-mediated inactivation of the Island cells axons enhanced trace fear conditioning learning. Thus, temporal associative learning can be regulated bidirectionally by the relative strength of MECIII and Island cell inputs to CA1. This suggests that this regulatory system controls the strength of a temporal associative learning as well as the duration of memory expression during recall. Additionally, the feedforward inhibitory input driven by Island cells may provide a specific pattern of temporal windows within which MECIII input can impact CA1 activity to drive the formation of specific associations between events. Although the feedforward inhibition of MECIII input to CA1 pyramidal cells by the ECIIi-SL-INs pathway serves as an important mechanism for the control of temporal associative memory, other circuits and/or mechanisms may also contribute to this process. For instance, 
recent studies described long-range projections of entorhinal interneurons into HPC interneurons, including SL-INs and hippocampal Somatostatin-positive interneurons (Melzer et al. 2012; Lovett-Barron et al. 2014). These circuits could also participate in the regulation of temporal associative memory by countering the effect of the ECIIi-SL-INs circuit.

\section{Hippocampal CAl time cells may bridge the gap between discontiguous events in an episode}

How do hippocampal CA1 cells encode a sequence of events and bridge the temporal discontiguity within an episode? Several groups have monitored activity from neurons in the CA1 during trace conditioning (McEchron and Disterhoft 1997; McEchron et al. 2003). On recall trials, some hippocampal CA1 cells signal the time at which the US is expected to occur, however during the trace there is generally no obvious sign of persistent activity reported when relatively long trace intervals are used (e.g., 20 $\mathrm{sec})$. Instead, neural activity patterns during the trace are generally heterogeneous across the population; there is not a dominant neural firing pattern that best describes most cells. In order to better understand how large neural ensembles of CA1 cells encode a distinct sequence of events, (MacDonald et al. 2011) trained rats on a sequence memory task that depends on the integrity of CA1 but not CA3 (Kesner et al. 2005). This task was similar to trace conditioning in that rats learned distinct object-odor sequences, wherein the object and odor event that composed the sequence were separated by a stimulus-free 10 -sec delay period. Large hippocampal CA1 ensembles were monitored from rats once they learned the task, and some CA1 neurons were activated during the critical object and odor events. However, more striking was that a large proportion of neurons activated in sequence during the delay, so that collectively the population of cells filled in the temporal gap and bridged the time interval between the object and odor (Fig. 4). Because each cell selectively activated at a specific moment during the delay, spatial/behavioral variables did not account for temporal modulation, MacDonald and colleagues referred to them as "time cells." In another experiment (MacDonald et al. 2013), head-fixed rats were presented with a sequence of two odors separated by a short delay period (e.g., $5 \mathrm{sec}$ ) and trained to report if the two odors composing the sequence were the same or different. Even though the rats were immobilized, largely distinct ensembles of time cells were activated in succession during the delay to represent the identity of the first odor, and the fidelity of the

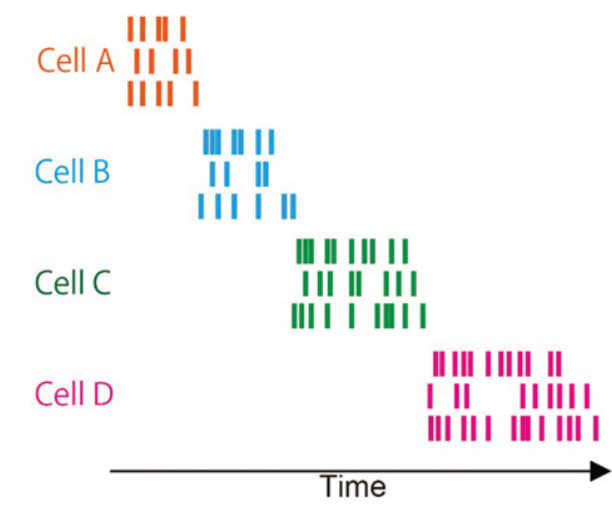

Figure 4. Time-cell firing sequences during trace period of memory task. Cartoon of a raster display of spiking activity recorded time cells. Each cell shown in a different color. For each cell, activity is shown as a raster of spikes for three example trials in which the cell fires for a brief period at approximately the same moment in each trial. time-cell sequence was predictive of the rat's success regarding if the odors in the sequence were the same or different. Consistent with this finding, Modi et al. used two-photon calcium imaging to visualize CA1 cells in mice during trace eyeblink conditioning. These authors found that neurons activated in succession during the short trace interval (500 msec) (Modi et al. 2014). Moreover, sequential activity emerged in CA1 over the course of learning in a way that suggested the strengthening of inputs originating from a common source.

Collectively, these findings suggest that the CA1 time-cell sequences provide a general mechanism by which distinct events separated in time may be bound together in memory. Indeed, CA1 sequential activity is also observed during the delay period of tasks such as the DNTP procedure described earlier; that is, tasks in which rats must alternate between taking different spatial routes on successive trials (Pastalkova et al. 2008; Gill et al. 2011; Kraus et al. 2013,). In a spatial alternation task, it was recently reported that time-cell sequences in the CA1 are profoundly disrupted by temporary inactivation of the medial septum during the delay period and performance was also impaired (Wang et al. 2015). Because the medial septum sends diverse and diffuse projections to the HPC and EC (Meibach and Siegel 1977), future work will be needed to tease apart the precise mechanisms at the heart of this disruption. Taken together, we suggest that persistent activity in the EC may also play an important role in the generation of time cells in CA1 (see also Hasselmo 2012; Hasselmo and Stern 2014).

\section{Conclusions}

We have summarized recent advances in our understanding of the roles of EC-HPC networks in temporal associative learning, an essential component of episodic memory. Future work is needed to determine how other areas contribute to this process at the circuit level (e.g., Bang and Brown 2009; Weiss and Disterhoft 2011), and how they may interact with EC-HPC networks. Behavioral studies of rodents in which the EC-HPC neuronal circuits are manipulated pharmacologically, genetically, or through lesions indicate that hippocampal-entorhinal neuronal networks are crucial for temporal associative learning. Cell-type-specific manipulations by using TeTX or optogenetics are beginning to reveal distinct mnemonic functions of different entorhinal-hippocampal circuits. Accordingly, MECIII cells are crucial for temporal associative learning, and Island cells in ECII are crucial for fine tuning this process. Together, these pathways bidirectionally strengthen or weaken the association between events separated in time. The MECIII cells and Island cells appear less important for spatial contextual memory. Instead, the hippocampal CA3 region may be crucial for the formation of spatial contextual memory (Nakazawa et al. 2003; Nakashiba et al. 2008). Thus, the trisynaptic pathway from Ocean cells in ECII to CA1 via the trisynaptic circuit may primarily process spatial context, whereas the direct pathways from MECIII and Island-SL-INs may be responsible for temporal properties of episodic memory.

The hippocampal CA1 network shows a robust hippocampal representation of event sequences through time cells, which selectively activate at specific moments during temporal intervals in between events composing the sequence. Collectively, time-cell ensembles may bridge the temporal gap between events within an episode. Although there is still no strong in vivo physiological evidence about the persistent firing in EC during trace conditioning, we speculate that one source of input into CA1 pyramidal cells is persistent firing in the MECIII that is triggered by the conditioned stimulus, and this input is modulated by Island cell activity (Fig. 5). This idea is also supported by a computational study 


\section{Delay fear conditioning}

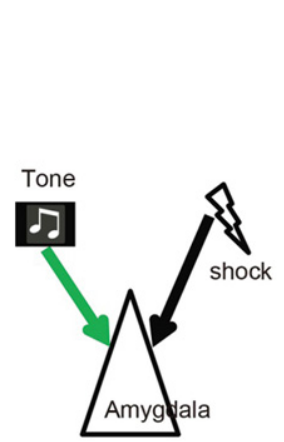

Trace fear conditioning

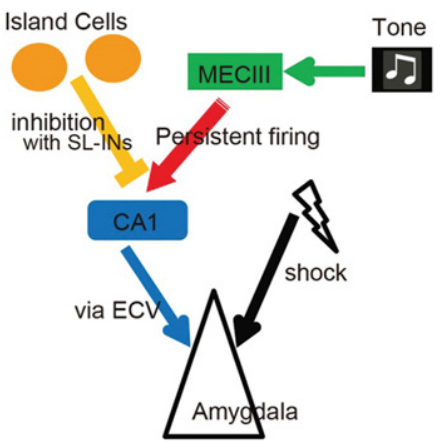

Figure 5. Proposed neuronal circuits for Delay fear conditioning and Trace fear conditioning. Circuits for delay fear conditioning (left side) is simpler and requires the conjunction of the CS (tone) with the US (shock) in the amygdala. Circuits for trace fear conditioning (right side) shows the brain regions underlying the association of the CS (tone) with the US (shock) across the trace interval.

on the contribution of persistent firing on time-cell activity (Hasselmo 2012; Hasselmo and Stern 2014; Howard et al. 2014; Saravanan et al. 2015). In this way, persistent firing is transmitted to CA1 pyramidal cells to bridge the temporal gap, and then to the amygdala via the EC layer V to coincide with the onset of the US (Fendt and Fanselow 1999) to generate a fear memory engram via Hebbian synaptic strengthening in the amygdala.

\section{Acknowledgments}

We thank all of the members of the Tonegawa laboratory for their support. This work was supported by RIKEN Brain Science Institute, Howard Hughes Medical Institute, and the JPB Foundation to S.T.

\section{References}

Alonso A, Klink R. 1993. Differential electroresponsiveness of stellate and pyramidal-like cells of medial entorhinal cortex layer II. J Neurophysiol 70: $128-143$.

Amaral DG, Witter MP. 1989. The three-dimensional organization of the hippocampal formation: a review of anatomical data. Neuroscience 31: $571-591$.

Andersen P, Morris R, Amaral D, Bliss T, O'Keefe J. 2007. The Hippocampus Book. Oxford University Press, New York.

Bang SJ, Brown TH. 2009. Muscarinic receptors in perirhinal cortex control trace conditioning. J Neurosci 29: 4346-4350.

Bi GQ, Poo MM. 1998. Synaptic modifications in cultured hippocampal neurons: dependence on spike timing, synaptic strength, and postsynaptic cell type. J Neurosci 18: 10464-10472.

Brun VH, Otnass MK, Molden S, Steffenach HA, Witter MP, Moser MB, Moser EI. 2002. Place cells and place recognition maintained by direct entorhinal-hippocampal circuitry. Science 296: 2243-2246.

Clark RE, Squire LR. 1998. Classical conditioning and brain systems: the role of awareness. Science 280: 77-81.

Egorov AV, Hamam BN, Fransén E, Hasselmo ME, Alonso AA. 2002. Graded persistent activity in entorhinal cortex neurons. Nature 420: $173-178$

Eichenbaum H. 2014. Time cells in the hippocampus: a new dimension for mapping memories. Nat Rev Neurosci 15: 732-744.

Esclassan F, Coutureau E, Di Scala G, Marchand AR. 2009. A cholinergic-dependent role for the entorhinal cortex in trace fear conditioning. J Neurosci 29: 8087-8093.

Fendt M, Fanselow MS. 1999. The neuroanatomical and neurochemical basis of conditioned fear. Neurosci Biobehav Rev 23: 743-760.

Frank LM, Brown EN. 2003. Persistent activity and memory in the entorhinal cortex. Trends Neurosci 26: 400-401.

Gill PR, Mizumori SJ, Smith DM. 2011. Hippocampal episode fields develop with learning. Hippocampus 21: 1240-1249.

Han X, Chow BY, Zhou H, Klapoetke NC, Chuong A, Rajimehr R, Yang A, Baratta MV, Winkle J, Desimone R, et al. 2011. A high-light sensitivity optical neural silencer: development and application to optogenetic control of non-human primate cortex. Front Syst Neurosci 5: 18.

Hasselmo ME. 2012. How we remember: brain mechanisms of episodic memory. MIT press, Cambridge, MA.

Hasselmo ME, Stern CE. 2006. Mechanisms underlying working memory for novel information. Trends Cogn Sci 10: 487-493.

Hasselmo ME, Stern CE. 2014. $\theta$ Rhythm and the encoding and retrieval of space and time. Neuroimage 85 Pt 2: 656-666.

Howard MW, MacDonald CJ, Tiganj Z, Shankar KH, Du Q, Hasselmo ME, Eichenbaum H. 2014. A unified mathematical framework for coding time, space, and sequences in the hippocampal region. J Neurosci 34: $4692-4707$

Huerta PT, Sun LD, Wilson MA, Tonegawa S. 2000. Formation of temporal memory requires NMDA receptors within CA1 pyramidal neurons. Neuron 25: 473-480.

Jochems A, Reboreda A, Hasselmo ME, Yoshida M. 2013. Cholinergic receptor activation supports persistent firing in layer III neurons in the medial entorhinal cortex. Behav Brain Res 254: 108-115.

Kesner R. 2013. Neurobiological foundations of an attribute model of memory. Comp Cogn Behav Rev 8: 29-50.

Kesner RP, Gilbert PE, Wallenstein GV. 2000. Testing neural network models of memory with behavioral experiments. Curr Opin Neurobiol 10: $260-265$.

Kesner RP, Hunsaker MR, Gilbert PE. 2005. The role of CA1 in the acquisition of an object-trace-odor paired associate task. Behav Neurosci 119: 781-786.

Kitamura T, Pignatelli M, Suh J, Kohara K, Yoshiki A, Abe K, Tonegawa S. 2014. Island cells control temporal association memory. Science 343: 896-901.

Klink R, Alonso A. 1997. Morphological characteristics of layer II projection neurons in the rat medial entorhinal cortex. Hippocampus 7: 571-583.

Knauer B, Jochems A, Valero-Aracama MJ, Yoshida M. 2013. Long-lasting intrinsic persistent firing in rat CA1 pyramidal cells: a possible mechanism for active maintenance of memory. Hippocampus 23: $820-831$.

Kohara K, Pignatelli M, Rivest AJ, Jung HY, Kitamura T, Suh J, Frank D, Kajikawa K, Mise N, Obata Y, et al. 2014. Cell type-specific genetic and optogenetic tools reveal hippocampal CA2 circuits. Nat Neurosci 17: 269-279.

Kraus BJ, Robinson RJ II, White JA, Eichenbaum H, Hasselmo ME. 2013. Hippocampal "time cells": time versus path integration. Neuron 78: 1090-1101.

Leutgeb JK, Leutgeb S, Moser MB, Moser EI. 2007. Pattern separation in the dentate gyrus and CA3 of the hippocampus. Science 315: 961-966.

Lovett-Barron M, Kaifosh P, Kheirbek MA, Danielson N, Zaremba JD, Reardon TR, Turi GF, Hen R, Zemelman BV, Losonczy A. 2014 Dendritic inhibition in the hippocampus supports fear learning. Science 343: $857-863$.

MacDonald CJ. 2014. Prospective and retrospective duration memory in the hippocampus: is time in the foreground or background? Philos Trans R Soc Lond B Biol Sci 369: 20120463.

MacDonald CJ, Lepage KQ, Eden UT, Eichenbaum H. 2011. Hippocampal "time cells" bridge the gap in memory for discontiguous events. Neuron 71: $737-749$.

MacDonald CJ, Carrow S, Place R, Eichenbaum H. 2013. Distinct hippocampal time cell sequences represent odor memories in immobilized rats. J Neurosci 33: 14607-14616.

Major G, Tank D. 2004. Persistent neural activity: prevalence and mechanisms. Curr Opin Neurobiol 14: 675-684.

Maren S. 2001. Neurobiology of Pavlovian fear conditioning. Annu Rev Neurosci 24: 897-931.

Marr D. 1971. Simple memory: a theory for archicortex. Philos Trans R Soc Lond B Biol Sci 262: 23-81.

Mattis J, Tye KM, Ferenczi EA, Ramakrishnan C, O'Shea DJ, Prakash R, Gunaydin LA, Hyun M, Fenno LE, Gradinaru V, et al. 2012. Principles for applying optogenetic tools derived from direct comparative analysis of microbial opsins. Nat Methods 9: 159-172.

McEchron MD, Disterhoft JF. 1997. Sequence of single neuron changes in CA1 hippocampus of rabbits during acquisition of trace eyeblink conditioned responses. J Neurophysiol 78: 1030-1044.

McEchron MD, Bouwmeester H, Tseng W, Weiss C, Disterhoft JF. 1998. Hippocampectomy disrupts auditory trace fear conditioning and contextual fear conditioning in the rat. Hippocampus 8: 638-646.

McEchron MD, Tseng W, Disterhoft JF. 2003. Single neurons in CA1 hippocampus encode trace interval duration during trace heart rate (fear) conditioning in rabbit. J Neurosci 23: 1535-1547.

McHugh TJ, Jones MW, Quinn JJ, Balthasar N, Coppari R, Elmquist JK, Lowell BB, Fanselow MS, Wilson MA, Tonegawa S. 2007. Dentate gyrus NMDA receptors mediate rapid pattern separation in the hippocampal network. Science 317: 94-99.

Meibach RC, Siegel A. 1977. Efferent connections of the hippocampal formation in the rat. Brain Res 124: 197-224. 
Melzer S, Michael M, Caputi A, Eliava M, Fuchs EC, Whittington MA, Monyer H. 2012. Long-range-projecting GABAergic neurons modulate inhibition in hippocampus and entorhinal cortex. Science 335: 1506-1510.

Modi MN, Dhawale AK, Bhalla US. 2014. CA1 cell activity sequences emerge after reorganization of network correlation structure during associative learning. Elife 3: e01982.

Morrissey MD, Maal-Bared G, Brady S, Takehara-Nishiuchi K. 2012. Functional dissociation within the entorhinal cortex for memory retrieval of an association between temporally discontiguous stimuli. J Neurosci 32: 5356-5361.

Moyer JR Jr, Deyo RA, Disterhoft JF. 1990. Hippocampectomy disrupts trace eye-blink conditioning in rabbits. Behav Neurosci 104: 243-252.

Nakashiba T, Young JZ, McHugh TJ, Buhl DL, Tonegawa S. 2008. Transgenic inhibition of synaptic transmission reveals role of CA3 output in hippocampal learning. Science 319: 1260-1264.

Nakazawa K, Quirk MC, Chitwood RA, Watanabe M, Yeckel MF, Sun LD, Kato A, Carr CA, Johnston D, Wilson MA, et al. 2002. Requirement for hippocampal CA3 NMDA receptors in associative memory recall. Science 297: 211-218.

Nakazawa K, Sun LD, Quirk MC, Rondi-Reig L, Wilson MA, Tonegawa S. 2003. Hippocampal CA3 NMDA receptors are crucial for memory acquisition of one-time experience. Neuron 38: 305-315.

Nakazawa K, McHugh TJ, Wilson MA, Tonegawa S. 2004. NMDA receptors, place cells and hippocampal spatial memory. Nat Rev Neurosci 5: $361-372$.

Pastalkova E, Itskov VA, Buzsáki G. 2008. Internally generated cell assembly sequences in the rat hippocampus. Science 321: 1322-1327.

Price CJ, Cauli B, Kovacs ER, Kulik A, Lambolez B, Shigemoto R, Capogna M. 2005. Neurogliaform neurons form a novel inhibitory network in the hippocampal CA1 area. J Neurosci 25: 6775-6786.

Ray S, Naumann R, Burgalossi A, Tang Q, Schmidt H, Brecht M. 2014. Grid-layout and $\theta$-modulation of layer 2 pyramidal neurons in medial entorhinal cortex. Science 343: 891-896.

Remondes M, Schuman EM. 2002. Direct cortical input modulates plasticity and spiking in CA1 pyramidal neurons. Nature 416: 736-740.

Ryou JW, Cho SY, Kim HT. 2001. Lesions of the entorhinal cortex impair acquisition of hippocampal-dependent trace conditioning. Neurobiol Learn Mem 75: 121-127.

Saravanan V, Arabali D, Jochems A, Cui AX, Gootjes-Dreesbach L, Cutsuridis V, Yoshida M. 2015. Transition between encoding and consolidation/replay dynamics via cholinergic modulation of CAN current: a modeling study. Hippocampus. doi: 10.1002/hipo.22429.

Solomon PR, Vander Schaaf ER, Thompson RF, Weisz DJ. 1986. Hippocampus and trace conditioning of the rabbit's classically conditioned nictitating membrane response. Behav Neurosci 100: 729-744.

Suh J, Rivest AJ, Nakashiba T, Tominaga T, Tonegawa S. 2011. Entorhinal cortex layer III input to the hippocampus is crucial for temporal association memory. Science 334: 1415-1420.

Suter EE, Weiss C, Disterhoft JF. 2013. Perirhinal and postrhinal, but not lateral entorhinal, cortices are essential for acquisition of trace eyeblink conditioning. Learn Mem 20: 80-84.

Tamamaki N, Nojyo Y. 1993. Projection of the entorhinal layer II neurons in the rat as revealed by intracellular pressure-injection of neurobiotin. Hippocampus 3: 471-480.

Tsien JZ, Huerta PT, Tonegawa S. 1996. The essential role of hippocampal CA1 NMDA receptor-dependent synaptic plasticity in spatial memory. Cell 87: 1327-1338.

Tulving E. 1984. Precis of elements of episodic memory. Behav Brain Sci 7: $223-238$

Varga C, Lee SY, Soltesz I. 2010. Target-selective GABAergic control of entorhinal cortex output. Nat Neurosci 13: 822-824.

Wang Y, Romani S, Lustig B, Leonardo A, Pastalkova E. 2015. $\theta$ Sequences are essential for internally generated hippocampal firing fields. Nat Neurosci 18: 282-288.

Weiss C, Disterhoft JF. 2011. Exploring prefrontal cortical memory mechanisms with eyeblink conditioning. Behav Neurosci 125: 318-326.

Yamamoto J, Suh J, Takeuchi D, Tonegawa S. 2014. Successful execution of working memory linked to synchronized high-frequency $\gamma$ oscillations. Cell 157: 845-857.

Yoshida M, Fransén E, Hasselmo ME. 2008. mGluR-dependent persistent firing in entorhinal cortex layer III neurons. Eur J Neurosci 28: 1116-1126.

Yoshida M, Knauer B, Jochems A. 2012. Cholinergic modulation of the CAN current may adjust neural dynamics for active memory maintenance, spatial navigation and time-compressed replay. Front Neural Circuits 6: 10.

Received March 23, 2015; accepted in revised form June 29, 2015. 


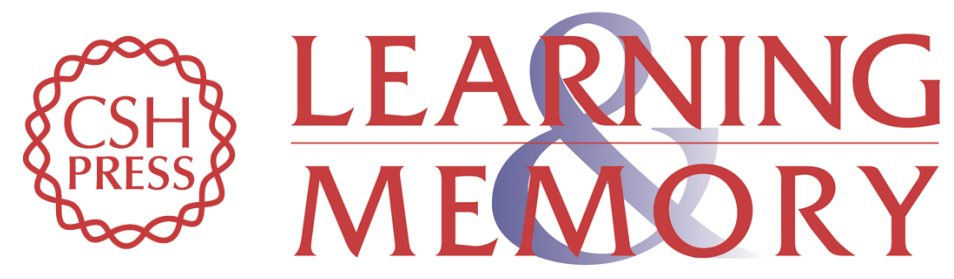

\section{Entorhinal-hippocampal neuronal circuits bridge temporally discontiguous events}

Takashi Kitamura, Christopher J. Macdonald and Susumu Tonegawa

Learn. Mem. 2015, 22:

Access the most recent version at doi:10.1101/Im.038687.115

\begin{tabular}{|c|c|}
\hline References & $\begin{array}{l}\text { This article cites } 66 \text { articles, } 21 \text { of which can be accessed free at: } \\
\text { http://learnmem.cshlp.org/content/22/9/438.full.html\#ref-list-1 }\end{array}$ \\
\hline $\begin{array}{r}\text { Creative } \\
\text { Commons } \\
\text { License }\end{array}$ & $\begin{array}{l}\text { This article is distributed exclusively by Cold Spring Harbor Laboratory Press for the } \\
\text { first } 12 \text { months after the full-issue publication date (see } \\
\text { http://learnmem.cshlp.org/site/misc/terms.xhtml). After } 12 \text { months, it is available under } \\
\text { a Creative Commons License (Attribution-NonCommercial } 4.0 \text { International), as } \\
\text { described at http://creativecommons.org/licenses/by-nc/4.0/. }\end{array}$ \\
\hline $\begin{array}{l}\text { Email Alerting } \\
\text { Service }\end{array}$ & $\begin{array}{l}\text { Receive free email alerts when new articles cite this article - sign up in the box at the } \\
\text { top right corner of the article or click here. }\end{array}$ \\
\hline
\end{tabular}

